\title{
The Role of Arab Welfare State on the Light of Globalization
}

\author{
Ali Mohammad Ali Al-Shboul ${ }^{1}$, Alaa Zuhheir Al-Rawashdeh ${ }^{2}$, Riyad Mofleh Khlaifat ${ }^{1}$ \& Asmaa Ribhi Al Arab ${ }^{2}$ \\ ${ }^{1}$ Department of Basic Sciences, AL-Huson University College, AL-Balqa' Applied University, Irbid, Jordan \\ ${ }^{2}$ Department of Social Sciences, Ajlun University College, AL-Balqa' Applied University, Ajlun, Jordan \\ Correspondence: Ali Mohammad Ali Al-Shboul, Department of Basic Sciences, AL-Huson University College, \\ AL-Balqa' Applied University, P. O. Box 50, AL-Huson, 21510, Irbid, Jordan. Tel: 962-77-704-9699. E-mail: \\ dr.alish68@yahoo.com
}

Received: October 8, 2012 Accepted: November 1, 2012 Online Published: December 31, 2012

doi:10.5539/ass.v9n1p68 URL: http://dx.doi.org/10.5539/ass.v9n1p68

\begin{abstract}
This sociological study analytical quality aims to identify the role of the welfare state Arab under the most important global changes which globalization it's economic, political, social and cultural rights. So come this paper to answer a series of questions about the concept of the welfare state when emerged, the justification of its existence, targets the welfare state, the concept of globalization $\&$ the foundations upon which the trends around. The study concluded that the globalization phenomenon carry many of the effects on the world, including the threat of states to withdraw their validity them and delivered to non-governmental organizations and institutions of an international character, and threaten security role Social adopted the welfare state Arab since it gained independence. Despite efforts to maintain the validity but it appears that the tide of change is much stronger than their capacity to resist. The study included a set of conclusions and offered solutions to the most important proposals and recommendations to address the status quo.
\end{abstract}

Keywords: globalization, state, role, care, welfare, Arab welfare

\section{Introducation}

Since their independence for specified, specified reasons and circumstance, the Arab states sought to adopt the welfare state's policy, in order to bring about the protection. The Arab states committed themselves to this role during the last decades, but it is clear that international changes pushes against this trend and Globalization was at the top of those changes due to it's characteristics related to the enhancement of capitalist countries' prominence within the context of economic, scientific and technical competition and the enhancement, enlargement of wealth and excellence. It became clear that the best method is not dependent on armies and military force, but on economy, money, technology and mass media. The decrease of the sovereignty of which takes that sovereignty in to the hands of international organizations (NGOs).

The Arab state is specifically liable to these effects due to its strategic position and its involvement as a party in the Arab - Israeli conflict, in addition to the weakness and inability it suffers on all levels, so that it found itself unable to deal with those conditions.

On the light of the above a question about the destiny of the role of welfare which was adopted by Arab countries arises.

\subsection{The Role of Welfare}

Social welfare development is defined as an essential and comprehensive system that aims at providing public and private services as needed, so that they become available for all the members of society without discrimination on social class, color, gender or religion, and it plays a role on the affecting of change and supporting positively and the reallocation of resources and controlling them (Mahrous, Mohammad Khalifah, 1986).

The philosophy of welfare state is based on assigning the responsibility of ensuring specified levels of income nutrition, health care, education and housing for every citizen and considering those services as basic rights for each individual.

The historical basis of the social welfare concept is related to the individual alms and aids' system that dominated the western countries since the endorsement of poor people aids laws in England in 1601, which made the 
concept interchangeable with the support provided to the poor and needy people (Mahrous, Mohammad Khalifah, 1986).

After the second word war the calls for welfare systems began to be bread in England and then they extended to most of the western European countries.

The essential ideas related to the welfare state were a reaction against the failure of the support systems based on the reforming model and its values which included the freedom, liberalism and individualism. This policy is also a strategy adopted by the capitalist regimes on the light of the success of communist model after the Belchevic revolution. The last stance was embodied in the calls for reforming the economic system and dealing with the social and economic problems, such as unemployment and the lack of stability, social and economic security among the labor forces.

\subsection{The Welfare Arab State and Its Rational}

Upon their independence the Arab states sought to find a method that can enable them to bridge the gap of lagging behind the developed countries and they held the belief that they will be able to move quickly a long the development route through planning, especially that planning was not a new concept, that it was mentioned during the liberation phase, and it was a method employed by the imperialist countries to calm down the revolting people and subdue the liberation movements which was beginning to disturbs the imperialist forces and causing them huge losses.

So The Arab states adopted the comprehensive social and economic development policy, which means that they didn't deal with the development as an economically pure issue, because the problems in any society are related and overlapping, so that it is wrong to ignore any of them " the development process should not be considered but as a civilized development process, that is huge and deep, and that it is an economic, social and political process in a comprehensive and complete way" (Alhout, Ali,1988)

The reason for that is the fact that the prerequisites for constructing a successful development are conditioned by making structural change to the Infrastructure and metadata within societies doing that was enviable, which means that the mentoring role of states is a natural beginning for that method.

But, the method of social welfare adopted in developed countries including Arab countries, is different from that which was adopted by Western countries which is due to the difference of the basic heeds in those countries for the achievement of comprehensive development (Mahrous, Mohammad Khalifah, 1986), meaning that the welfare rights should be achievable according to their real volume in society, and that they are not available only at the time in which no guarantees are present that they are provided to the needy. So the adoption of social welfare method is dictated by the deterioration in the social and economic conditions that characterized the opening years after the independence, which can be eliminated the previous classes characterized by the prominence of land- owners and tribal headsmen and elders who exercise wide economic, social and administrative authorities. That system collapsed and no new system took it's place, despite the emergence of professionals, administrators and technicians who supported the new social order, the old system had still some of its influence on the new system which created a kind of now - uniformity interims of its structure and the expatiations related to roles and duties within it. Additionally, in most cases the old social system creates obstacles to the process of satisfying the needs of citizens (Alhout, Ali, 1988)

Additionally, the increasing civilization levels related to the migration from the countryside and the resulting overpopulation in cities led to the incurrence of unemployment rates and a huge increase in the percentage of poor people.

Those conditions transformed the developmental role of the state and" transformed the guardian state in to a welfare state through the extension of the governmental activities toward the economic and cultural aspects and later to the intervention of state" (Jreisate, Jameel, 1988).

Additionally, there are other reasons including the following:

1) That there are historical reasons behind the dominance of state over the developmental activity, that can be a scribed to the control over money and business through the Colonial authorities, which prevented the emergence of a national private sector that is strong and able to carry the development responsibilities.

This inability was embodied in the lack of initiatives to satisfy the needs and deal with the investment opportunities that emerged in the Arab countries after their independence which forced the governments to create the required initiatives. 
2) The aftermath of imperialist control required that the governments undertake set of tasks in a way that is not related to a specific time or place, which include the task of creating the economic development which is a constant growth in the levels of living and material consumption. The content of education, health, protection of environment, as well as the provision of equal opportunities for all citizens so that they are enabled to participate in the production of that development and enjoying its results, lastly the provision of political freedoms and the protection of national rights for all citizens without discrimination.

3) The period that succeed the in depended was characterized by a direct and quick trend during the 1950s and 1960s towards the concentration of political and economic powers and the nationalization of resources including the social and economic domains.

4) The involvement of Arab states in economy and society was similar to their involvement in politics and culture resulting from their dictatorial nature more than many other factors and the rejection of the theories of development. The theory of intervention was used extensively and it employed the monopolistic attitude.

The accumulation of surplus which was incensing component ally since 1970s due to the rise in the prices of oil and the increase in its production at the same time, which enabled Arab oil countries to increase the levels of their expenditures which were above the required in some cases.

\section{Aims of Welfare Arab State}

The aims which the Arab welfare state sought to achieve were as follows:

\subsection{Decreasing the Poverty Levels}

Elimination of poverty was one of the main social aims sought by governments. Most governments employed a number of policies in order to achieve that ranging from the provision of monetary aids for the poor people, health insurance and unemployment insurance as well as pensions, educational support, housing so that minimum level is provided to the poor people and the elimination of poverty or at least, decreasing the number of people living under the poverty levels. And the handling of the problems arising from poverty which are considered as the social introduction to the other problems within the society on the basis that poverty has a direct influence on educations health, nutrition, housing and unemployment (Khater, Ahmad Mostafa,, 1988).

\subsection{Employment}

The Arab communities witnessed high rates of growth in population, considered among the highest rates in the world accompanied by a growth in the lab our forces which require the provision of opportunities for these forces. This is one of the most important challenges facing the Arab countries especially, because most of Job seekers are first - time seekers from among the youth.

\subsection{Education and Health}

The Arab governments thorough their role in funding education and health aimed at the provision of services directly to the majority of people, the improvement of the quality of those services and the achievement of equality of opportunities, so that all people can reach the educational services, the justice in the provision of educational and health services.

\subsection{Basic Structures}

The previous services can't be provided to the citizen without basic structures. The governments were the most able party in terms of investing in basic structures projects and managing them, despite the fact that most governments didn't have the resources required. So, they sought external loans to fund the projects. Additionally, the population's growth and its requirements in the economies of Arab states exerted their pressures on the available basic structures.

\subsection{Globalization and Its Effects}

The end of the twentieth century was characterized by a new phenomenon which is the globalization, whose meaning is not clear and varies based on the authors and their ideologies. The definitions of globalization are classified mainly in two trends controlled by prejudices. The first trend is biased on its behalf and claims that globalization is inevitable and the second trend rejects me completely, claiming that it is a recreation of the capitalist regime of dominance that existed in the past. Between the two trends, a third trend exists and it calls for a ware interaction with the Globalization towards the maximization of benefits it promises and decreasing the social costs related to it (Ala, Alrawashdeh, 2008).

Globalization as a concept is derived from the English word Global Village, meaning international as a concept it refers to the Global village, meaning that the world is a single global village. 


\subsection{The Bases of Global}

Globalization is based on the following bases: (Alhout, Ali, 1988)

The freedom of movement of commodities through the culmination of obstacles and borders from the way of international trade movement dominated by the United states of America, the common European countries market and Japan. As well as working towards the merging of global economies within single economy controlled by industrial developed countries towards the slogan of the liberation of markets.

1) The Adoption of privatization of all industrial, an agricultural, transportation, infrastructure sectors and the selling out of the public sector.

2) The freedom of the surplus capitals movement in the rich countries ,directing them in to the countries and sectors with the highest returns so that it forms a global market ford the capitals characterized by the lack of borders.

3) The free movement of labor, the lost Job opportunities and the purchase of thinking minds from the developing countries.

4) Decreasing the role of state in the economic, social domains, opening the door for the dominance of international organizations and multi - national companies.

\section{Decreasing the Role of State in the Economic and Social Life}

The Geo-economic considerations will control the international order, so that the economic interactions between the countries will have the upper hand in defining the foreign policies of the countries and defining their national interests. The last decade witnessed several regional blocs such as the European Union and Asian, as well as, Opik which aims at achieving the economic interests of the member counties. The multi-parties relations also increased which makes globalization to seem not as a process of sovereignty. Transfer from the national states in to a set of new organizations that are trans-national through which authorities are transferred from the hands of the national country in to the public and private international entities which will undertake more and more tasks that were undertaken previously by the state (Mahrous, Mohammad Khalifah, 1986).

These tasks include the issues of pollution and communications among others which leave the national countries with two alternatives either they resist those policies and the pressures exerted by those entities, which subject them to the danger of bankruptcy or that they accept those calls which may lead to severe social problems.

1) the rules and principles set by the GAT Agreement and the world trade organization (WTO) as well as the restrictions set by the world fund and the control over the state in terms of the monetary policies through the privatization programs and the structural cooptation and economic fixation, all that makes the borders of the country as if they were virtual borders a cross which the multi - national companies move with absolute freedom enjoying the economic and political powers which make them able to direct the policies or country towards their interests.

2) The idea of Sovereignty moves to the back ground when it is necessary for the country to reconsider its national legislations, in case they were not compatible with the laws and legislations of the new international organizations.

3) In reality, the essence of policy is that it is a function exercised by a certain country in the light of the international law, the enlargement of the content of the later, led to the as sighing the right to intervene in the affairs of other countries to some international organizations (namely, the United Nations), and in some cases, specific countries were delegated for the execution of that intervention ( $\mathrm{Abd} \mathrm{Al}$ - Hussein, Wadi $\mathrm{Al}$ - Altiah, 2001).

4) Globalization leads countries into the direct interaction with the national non- governmental organizations, which receive their funding mainly from the American development Agency. According to Al - Gore, the former vice - president half of the formal American aids and that the expenditures of the Euro - midiron on companion ship has rules that provide the European Union with the right to create direct links with the non - governmental organizations within the Arab countries that are members of it's a agreements without referring to the state (Globalization and its repercussions on the Arab world, 2003).

So weakening the authority of the state dissolves it in entities large than itself and which press it towards the a abandonment of its independence and its sovereignty on its region. Additionally, this leads to belonging to smaller ethnic entities such as the tribe, religion and section which may lead consequently in to ethnic conflicts.

So, the authorities of the state move upwards in to the hands of International organizations such as the Security 
Council and downwards in to the hands of governorates and public organizations, syndicates and sideways where the stronger countries, non - Governmental Organizations and Multi - national companies do exist.

In addition to the role played by Globalization in weakening the sovereignty of state, Globalization also ignores the social aspect in the economic developmental process and the subjecting of all the aspects of social and political life to on absolute standard - that is the profitability of the capital, as well as, the legalization of a number of domains such as lab our international trade. In this context the authors of the book titled (The trap of Globalization) raise the question: Does the welfare state become a threat to the future and that a degree of social inequality is inevitable (Peter, Hans and shawnan, Harold, 1998).

In addition to the effects of Globalization there are other circumstances that show symptoms of the withdrawal of the Arab country and it's a abandonment of its responsibilities related to the support of citizens and the expenditures related. These symptoms do not seem voluntary, but are a result of pressures that led in several cases in to a kind of chaos.A Chaco that is demonstrated in the loosening of the state power including the deterioration of its role in education and the dominance of the private sector in that field and employing it for the purposes of the accumulation of wealth. Even the army is no more a national force, but a fragile guardian for the ruler. What we are witnessing nowadays is the collapse of the social contract that was established during the 1950s between the state and the society, which was built on the basis that the state provides the individual with the protection and social welfare to the maximum degree within its capabilities, on condition that the individual does not exercise any political activity of any kind (kanan, hamdi, taher, 1997).

\section{Those indicators include:}

1) that the role of Arab welfare state and the intervention method are all based on its role in providing the security and defense, especially that the Arab region has witnessed several conflicts and tensions. The question that arises here is whether the political settlement of the Arab - Israeli conflict will lead to the enhancement of the role of the private sector.

2) the beginning of the role of state's deterioration came as a results of the collapse of the Eastern block and the withdrawal of central planning systems, as well as the extension of the ideas of political Islam not among the public only, but also among the cultured class from among the members of professional syndicates. The question ought to be raised here concerns the degree to which the ideas of political Islam can be considered as "market friendly". This is not surprising due to the Islamic respect of individual ownership, freedoms and individual rights, and the duty related to their protection along the justices in terms of the distribution of wealth and social integrity and responsibilities of the ruler in this issue (Kamesh, Majed Aldien, 2005)

3) The economic reforms of the Arab governments and their application of the privatization policy which doesn't accept the intervention of the state or its speaking of prices led to surplus in demand and consequently to the consumption of resources.

This situation threatens the future of the Arab welfare state and it had created tensions and deterioration of the conditions of the Arab citizen. This requires handling the issues wisely and the enhancement of the states role as well as its validity and control over the situation based on the requirement that the role of the state corresponds to its functions. The concentration of the state's abilities at the beginning on the vital functions such as the provision of the basic structure and Justice, preventive health and later to be extended towards other functions based on the state's capabilities for the capable state to be an effective and functional state, it needs to employ its capabilities in behalf of a small group of people only (Abd Al - Hussein, Wadi Al - Altiah, 2001).

This requires also the maximization of the organizational capabilities of the state through the strengthening of its public organizations, which requires doing the following:

1) preventing the monopoly of authorities and the control of decision making as well as fighting corruption.

2) working towards maximizing the efficiency of organizations that provide the public services and strengthening the execution apparatus through exposing those organizations to competition which puts them in front of the real situation and forces them to improve their performance so that they may survive.

3) Opening the way for the participation of society in expressing its need and providing the opportunity to the civil society organizations and enhancing Decentralization in Administrative work.

It can be noted also that the international organizations such as the United Nations had increased their efforts in launching campaigns aiming at providing the social welfare and making the development a reality for all people. Those efforts aims at extending Globalization and making it more fair as well as the achievement of development in the international society, eliminating poverty and accelerating economic growth in the 
developing countries.

\section{Conclusion}

From what welfare stated previously, it becomes clear that Globalization is a phenomenon that has several effects on the world which include threatening the states through the cut of their powers in behalf of nongovernmental organizations and international entities. It threatens consequently the social role related to security which was carried out by the Arab welfare states since their independence despite the efforts exerted for the maintaining of their viability but the change trend seems stronger than their resisting capacities.

Despite the efforts of the international organization in terms of working for the provision of welfare services which support the states efforts, several questions are raised concerning the honesty of those calls, the related intentions and the degree of independence enjoyed by those organizations in relation to the international powers which sets the economic interest above all other considerations.

\section{References}

Ala, A. (2008). Globalization and the community. Hamid Publishing and Distribution, Amman.

Alhout, A. (1988). The bases of Development and Social planning. Dar Al-Hikma, Tripoly.

Al-Hussein, A., \& Al-Altiah, W. (2001). Developing economics: Crises and Solutions. Dar Al-Shorook, Amman.

Globalization and its repercussions on the Arab. (2003). Globalization and its consequences in the Arab World. Arab- Union research center, Beirut.

Jreisate, J. (1998). Managing the Arab Development in the light of the Non-methodical policy. Dar Al-Faris, Amman.

Kamesh, M. A. (2005). State and Arab development in a globalized world. Majdalawi Publishing and Distribution, Amman.

Kanan, H. T. (1997). Role of the state in Arabian economical environment. Nadweh alarabi.

Khater, A. M. (1998). Social planning. Al-Maktab Al-Hadeeth, Alexandria.

Mahrous, M. K. (1986). The social policy and planning in the third world. Dar Al-Makefa Al-Janeia, Alexandria.

Peter, H., \& Shawnan, H. (1998). The Trap of Globalization, translated by Abbas Ali, Kuwait.

The Role of State in the economic structure in Modern Arab world. (1997). A forum of the Arab fund for Social and Economic Growth and Arab Monetary fund, March, Kuwait. 